\title{
ON THEIR OWN: TOWARDS AN ANALYSIS OF SEALERS' SITES ON HEARD ISLAND
}

\author{
by Angela McGowan
}

(with nine text-figures and six plates)

\begin{abstract}
MCGOWan, A., 2000 (30:vi): On their own: towards an analysis of sealers' sites on Heard Island. In Banks, M.R. \& Brown, M.J. (Eds): HEARD ISLAND PAPERS. Pap. Proc. R. Soc. Tasm. 133(2): 61-70. https://doi.org/10.26749/rstpp.133.2.61 ISSN 0080-4703.

Cultural Heritage Branch, Department of Primary Industries, Water and Environment, GPO Box 44A, Hobart, Tasmania, Australia 7001.

Heard Island is possibly the remotest speck of land on the Earth. It was only in the 185 s that the human race finally reached this most isolated of places. For the next 30 years gangs of hunters established themselves on the isolated beaches of Heard Island to slaughter the wildlife for their oil and furs and ship the products to markets half-way around the globe. The material culture remains of these enterprises survive on the beaches, comprising the remnants of the seal-hunters' camps and their processing sites. These sites provide evidence of 19 thcentury sealing technology and the diverse ethnicity and cultural composition of the sealing gangs. Remains of sealers' camps are found on many of the beaches around Heard Island but are now extremely threatened by coastal erosion. Many of these sites include tryworks situated on raised stone platforms, a form of sealing architecture thought to be unique to Heard Island.
\end{abstract}

Key Words: cultural heritage, archaeology, Heard Island, sealing, industrial archaeology.

\section{PREAMBLE}

This paper is a more detailed version of one I gave at the Heard Island workshop held at the Australian Antarctic Division from 29 June to 1 July 1998 (McGowan 1998, Selkirk 1998). My objective was to present something of the variety of historic sealers' sites on Heard Island and to demonstrate some of the complexity and potential of the archaeology of the sealing industry. My unashamed purpose was to encourage the Antarctic Division to manage the cultural resources on Heard Island pro-actively while the resource still exists, and to give a high priority to supporting aserious programme of archaeological research in the coming $1999 / 2000$ field season. These sites are highly threatened by and vulnerable to both coastal erosion and the wildlife. What is left of this unique record of 19th-century life will not survive for much longer. The site information in this paper is based on my visit to Heard Island some twelve years ago in 1986. Other papers given at the workshop will show that the sealing beaches have eroded so much that some site locations may now have disappeared and others are severely threatened (Green 1998, and herein, p. 27). It would not be an exaggeration to describe the situation as a crisis which demands an adequate response. In my opinion, the highest priority would be to undertake high-quality archaeological research targeted at the most vulnerable sealers' sites.

\section{INTRODUCTION}

At $53^{\circ} \mathrm{S}$ in the Southern Ocean, Heard Island is arguably the most remote speck of land in the world. It is over $4000 \mathrm{~km}$ from Fremantle and about the same distance from South Africa. The nearest land is the bleak Kerguelen Islands group about $466 \mathrm{~km}$ to the northwest.

Heard Island is about $40 \mathrm{~km}$ long by $26 \mathrm{~km}$ across and is dominated by a $2750 \mathrm{~m}$ high active volcano, Big Ben the highest mountain in Australia (and still growing!). About $80 \%$ of the island is covered with ice, and there is considerable evidence that, in the 19th century, the ice cover was even more extensive (Allison \& Keage 1986,
Budd 1998). Today, many of the glaciers terminate in icy lagoons separated from the sea by low, stony terminal moraines, which give access from one beach to another. A hundred years ago, most glaciers came down to the sea, terminating in huge ice cliffs and effectively isolating the sealing beaches as pockets of settlement. These beaches are where the seals congregate, and where the sealers who hunted them lived and worked.

Communication across the glaciers was difficult and hazardous. In this paper, I argue that isolation is a recurring theme for understanding the archaeology of Heard Island: - the isolation of Heard Island itself,

- the social isolation of various ethnic groups in the sealing gangs (apparent from the historic sources and perhaps potentially identifiable in the archaeological record),

- the isolation of the product from its market.

The most abundant species of seal is the Southern Elephant Seal, Mirounga leonina, which the sealers hunted for oil. Also common is the Antarctic Fur Seal, Arctocephalus gazella, which may have been a minor prey species (Shaughnessy et al. 1988).

General descriptions of the geography and natural history of Heard Island were given by Keage (1981), Shaughnessy et al. (1988) and other papers in this publication. A definitive comprehensive history of the sealing industry on Heard Island has not yet been written. Neither was this an objective of this archaeological survey. Such a project would complement and provide an essential context for understanding the significance of the material culture remains (the archaeology) of the island. A number of works deal with various aspects of this history, and the historical summary presented here draws largely on these works (Bertrand 1971, Busch 1980, 1985, Downes 1996, Richards 1981, Roberts 1950).

Heard Island was apparently discovered and exploited quite late in the history of the southern sealing industry. The Kerguelens were discovered in the 1770s and have been exploited for seals since then. The discovery of Heard Island occurred much later, although the exact date is a matter of controversy (Bertrand 1971: 228-229, Roberts 1950: 580, Shaughnessy et al. 1988). The first sightings 
may have been kept secret to protect commercial interests. The discovery was reported by Captain John Heard in 1853 , followed by the first recorded sealing expedition in 1855. Sealing continued vigorously and unabated for about 30 years until the 1880 s (Downes 1996). One firm, the South African based Kerguelen Whaling and Sealing Co., resumed sealing during the 1920s (Busch 1980: 125, Roberts 1950: 588). It was at this time that the British Admiralty commissioned some sealers to build a small wooden hut, the Admiralty Hut, at Atlas Cove (Keage 1981: 14).

Most sealing enterprises on Heard Island were American. They operated out of New London, Mystic and other New England ports, and were based primarily at the Kerguelen Islands. During these expeditions, captains would cross to Heard Island where they would drop off one or more gangs of sealers for the summer. In many cases the gangs stayed a full year, so that they could continue sealing while their ship took home a cargo of oil (Busch 1985: 171-172).

The ships rarely stayed long, due to the difficulty of finding a safe anchorage. The weather at Heard Island is extremely unpredictable and changeable. Access to the sealing beaches around Heard was difficult - a dangerous trip through the surf or a traverse across a crevasse-ridden glacier. Mostly the gangs stayed where they landed - they were on their own.

In this paper, I look at the distribution of the suite of sites associated with the 19th and early 20th century sealing industry, and at the differences between sites at various locations around the island. This analysis is based on the fieldwork undertaken in 1986/87, when over 20 sites were recorded on beaches around the eastern, southern and northwestern ends of Heard Island. I also argue that a number of formal differences can be identified between the remains found at the eastern and those at the northwestern ends of the island. All the eastern sites show such similarities of form that they are almost certainly from the same or related operations, and probably date from the last sealing expedition in the $1880 \mathrm{~s}$. Here, there seems to have been a distinct separation between living and work areas.

Figure 1 shows the locations of sealers' settlements mentioned in this paper.

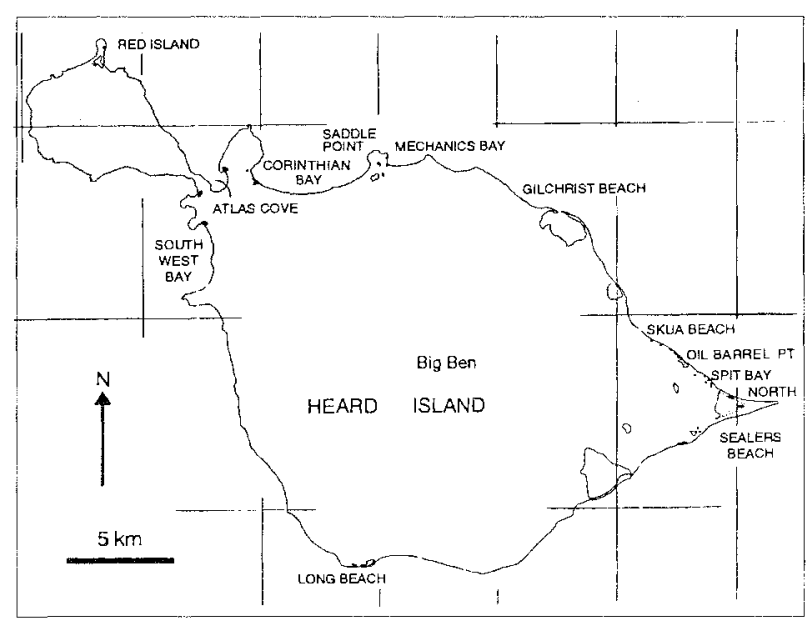

FIG. I Location of sealing sites recorded at Heard Island 1986-87.

\section{Documentary sources}

Historical documentation relating to the sealing industry on Heard Island consists of captains' logs and memoirs and 19 th-century American seal fishery statistics. Most of these are located in America and available to Australian researchers only through various secondary sources (Busch 1980, 1985, Clark 1887, Downes 1996, Nunn 1850, Richards 1981, Roberts 1950). One notable exception is the memoirs of Captain James Robinson, a Tasmanian sealer of American descent, who led an expedition to Heard Island for Dr W.L. Crowther in 1858. His memoirs are held by the State Library of Tasmania (Crowther 1940, 1943, 1970, Robinson n.d.). Also available are the published accounts of the Challenger scientific expedition which visited Heard Island in 1874, making contact with a sealing gang stationed there (Campbell 1876, Moseley 1879, Thomson \& Murray 1885).

\section{THE ARCHAEOLOGICAL DATA}

Following a detailed and carefully documented report of sealing remains by biologist Harry Burton in 1985 (Burton \& Williams 1985), my colleague, Estelle Lazer, and I spent two months on Heard Island in the summer of 1986-87 as members of an ANARE expedition (Ledingham 1987, McGowan 1988). Our major project was to conduct a preliminary inventory survey of sealing sites and make appropriate management recommendations (Lazer \& McGowan 1987, 1989, McGowan 1988, McGowan \& Lazer 1988).

We identified four different types of sealing sites: stone platforms, hut footings or ruins, occupied caves and barrels. Two other site types have also been recorded by previous and subsequent expeditions. These were graves at South West Bay and Corinthian Bay (Burton \& Williams 1985: 46, Robb 1988: 155) and an occupation pit at Corinthian Bay (Robb 1988: 155). In addition, there were many isolated sealers artefacts scattered across the beaches, including pieces of trypots.

\section{Stone platforms}

Elevated stone work platforms were constructed at a number of locations on the southern and eastern beaches. We found them at several Spit End beaches and at Long Beach. Artefacts found on and around the structures confirmed that they date to the first sealing period in the second half of the 19th century. As far as my colleague and I are aware, these stone platforms are a form of sealing architecture unique to Heard Island. Nothing like them is reported from Marion Island or Prince Edward Island (Cooper \& Avery 1986), Macquarie Island (Townrow 1989) or the sealing islands around Tasmania, such as the Ile de Phoques (pers. obs.), Preservation Island and the other Bass Strait Islands (pers. obs., Harris 1988).

The platforms were constructed from large beach cobbles built into subcircular mounds, ranging in size between $4 \mathrm{~m}$ and $17 \mathrm{~m}$ across. Typically these mounds are located above the shoreline on flat coastal plains heavily dissected by seal wallows. The wallows consist of deep boggy patches between elevated clumps of vegetation such as tussock grass or Azorella. Evidently the stone platforms were built to elevate sealing activities above the general level of the wallows and 
were ab out half a metre high. Most of the platforms have themselves been dissected by seal wallowing, especially around their edges, and in some instances it was difficult to determine a boundary for the edge of a mound, particul arly where rocks occur naturally in the area. The function of the platforms was apparently as working platforms and the more intact ones supported remains of tryworks including trypots, flensing floors and other equipm ent.

Five mounds had sealing artefacts associated with them. The largest of the mounds, at Spit Bay North, had substantial remains of a tryworks (fig. 2, pl. 1) including four surviving trypots and pieces of a fifth, a fire-box made of bricks and iron beams, a scrap blubber press and the remains of a large flensing floor. Two other mounds in the Spit End region had trypots and/or other tryworks equipment on or immediately adjacent to them.

These were at Sealers Beach, where the mound also incorporated bricks and had trypots and a copper oil tank (fig. 3, pl. 2), and at Trypot Beach, which had a trypot. One other mound at Spit Bay North had associated with it a wooden flensing floor (fig. 4) and a blubber skimmer, mentioned by Burton \& Williams (1985: 50) but not recorded by us in 1986-87. Another had several sealing tools. Two mounds had no diagnostic artefacts found with them. These were the smallest mound at Spit Bay North and the mound at Long Beach. The location of all these mounds close to the shore and exposed to the unhindered winds suggests that these mounds were sited for working convenience rather than domestic comfort.

It is not clear what sort of structures were built on the platforms at Spit End, but they were most probably made of wood. Two platforms supported wooden floors, built from an apparently random selection of beams, planks and unworked timber. Another platform had what may be either the remains of a floor or part of a collapsed wall. Timber pieces of various shapes and sizes found lying alongside each other have been interpreted as floors. Groups

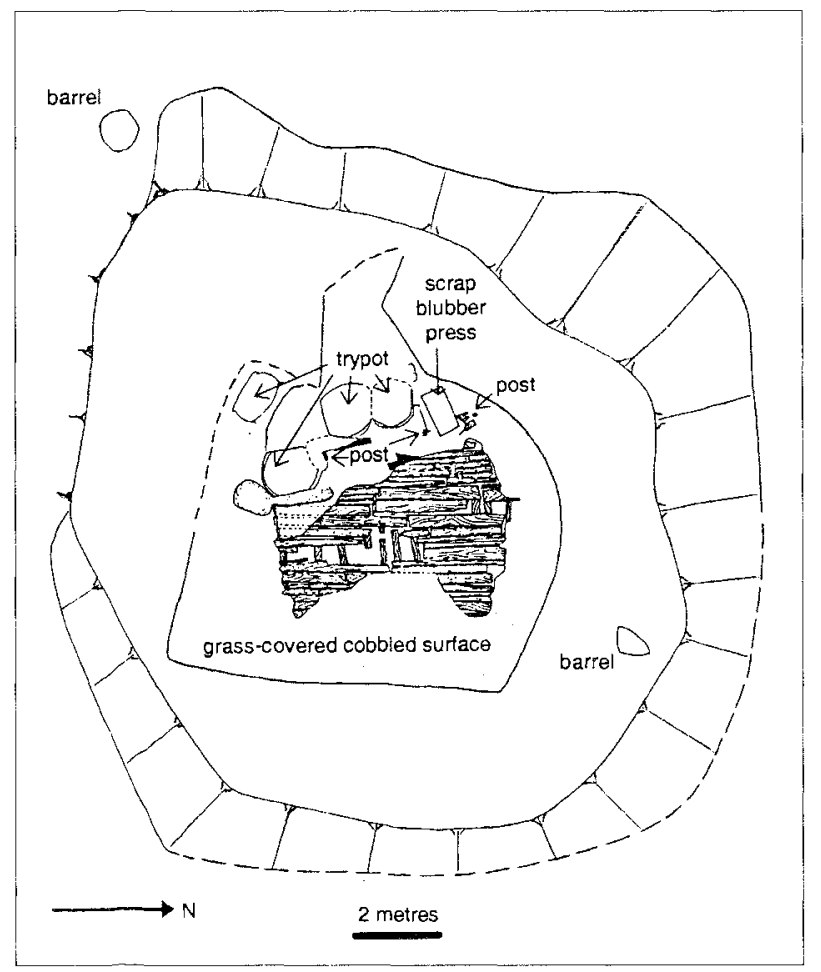

of similar planks or boards found lying in disarray have been interpreted as collapsed walls. The large tryworks at Spit Bay North had two wooden uprights between the firebox and the wooden floor, and these may have contributed to the support of a roof of some kind. There are two illustrations drawn in 1883 of an 1860 expedition, which show sealers working at the Spit and rolling barrels towards a tryworks (almost certainly the Spit Bay North site) sheltered under a roof supported by four upright posts and with open sides (reproduced in Downes 1996: 61, 87). Despite the lack of any substantial evidence for walled structures, it is hard to imagine that the sealers did not erect some protective windbreaks on their working platforms.

The one exception to the above general description and possible interpretation was the hut mound at Long Beach, a stone platform supporting a hut with stone footings. Its location in the wallows implies the mound initially had an industrial function (although no remains of tryworks equipment were noted to support this), with domestic functions being accommodated in the small cave on the moraine. Later, it was probably used as the platform for a domestic hut.

\section{Barrels}

Barrels and barrel pieces are widespread across the beaches of Heard Island. The distribution of isolated barrel pieces is probably the result of dispersal by the wind rather than representative of the original location of barrels. Where barrels are found eroding out of the ground or where there is a group of iron components, the site is probably at its original location.

Barrels were used to contain food and other goods such as coal, as well as to store and transport blubber and oil (Bertrand 1971: 249, Campbell 1876, Moseley 1879: 229). Therefore, their presence is not specifically diagnostic of either industrial or domestic activities.

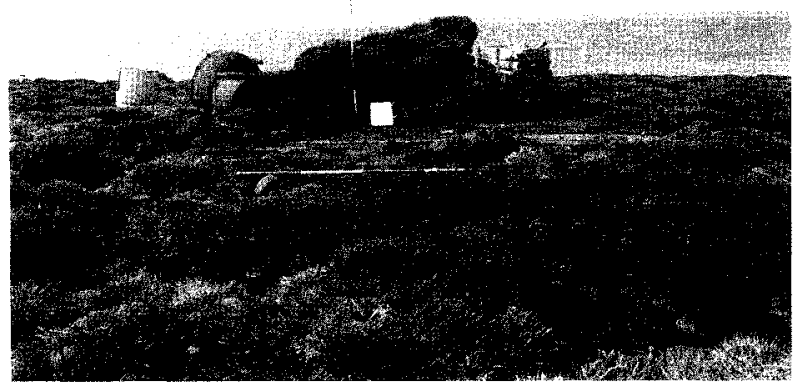

PLATE 1

Spit Bay North tryworks mound.

FIG. 2 - Plan of tryworks mound at Spit Bay North, Heard Island 1986-87. 


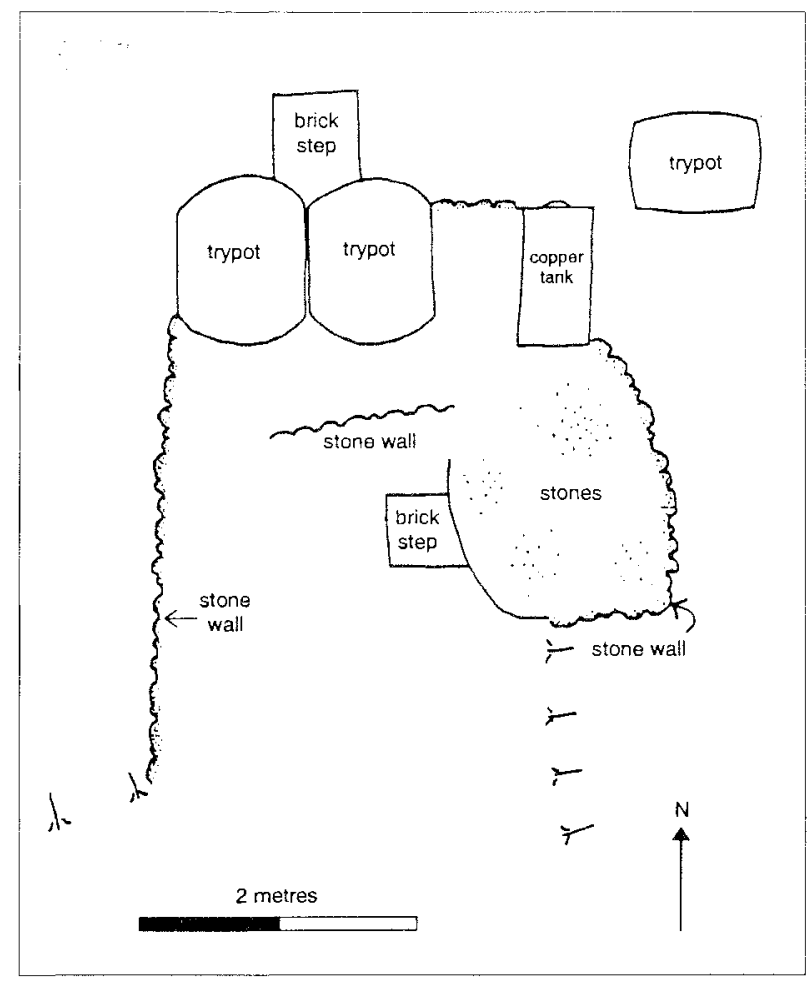

FIG. 3 - Plan of tryworks at Sealers Beach, Heard Island $1986-87$.

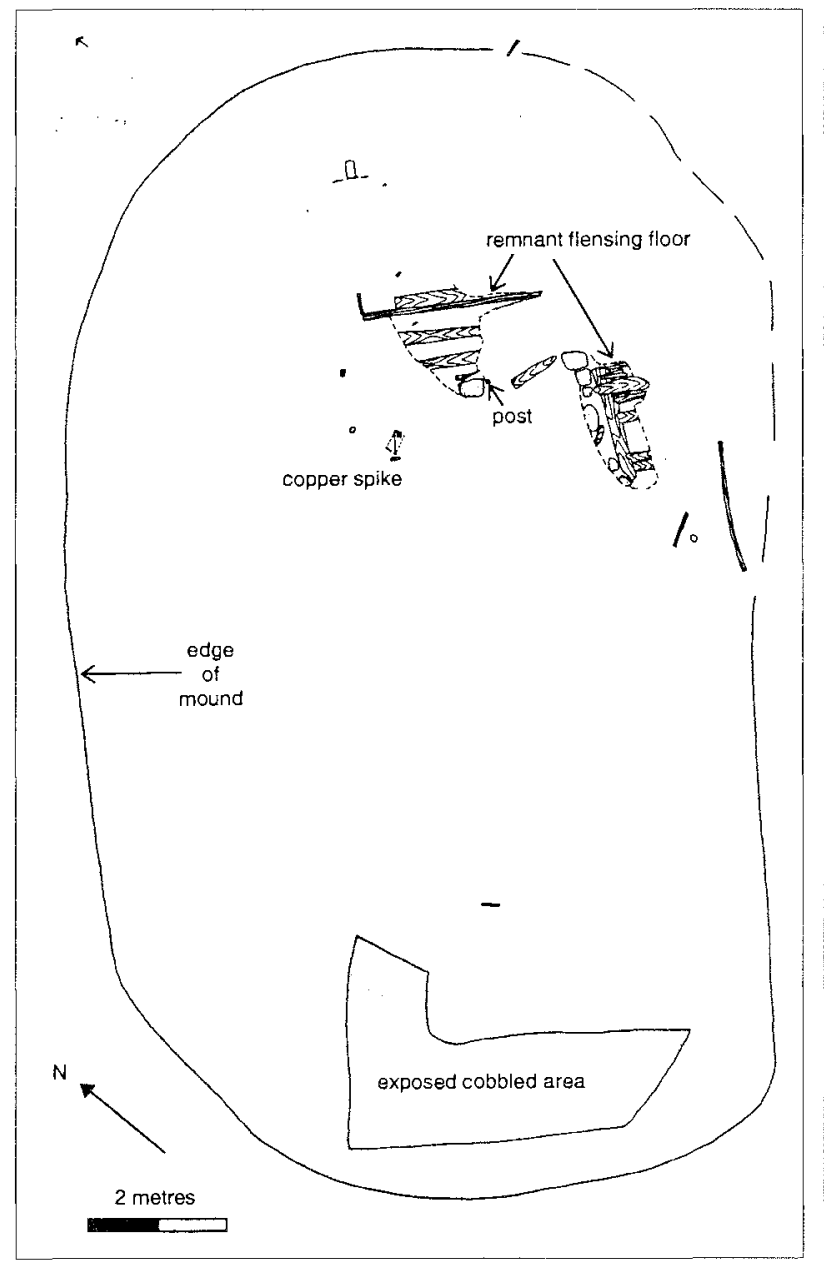

FIG. 4-Plan of stone platform at Spit Bay North, Heard Island 1986-87.

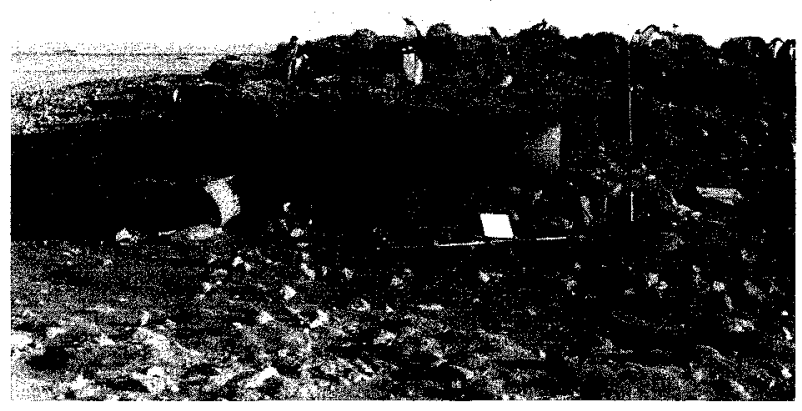

PLATE 2

Sealers Beach tryworks mound.

Two sites may be cooperage sites, where barrels were put together, although in both cases the evidence is inconclusive. One of these, at Spit Bay North, contained a large collection of coopering iron, sealing tools and ships' dunnage, which suggests that a cooperage and tryworks had been in this area. No structure was found in the vicinity, although Burton \& Williams (1985: 51-52) reported an extensive scatter of clay smoking pipes nearby. At Sealers Beach, a small brick and stone structure with associated barrel components may have been the cooperage for this settlement.

There were two barrel caches. The largest, at Oil Barrel Point, comprised 35 barrels (in 1986) lying on their sides in two rows supported by lines of rocks (fig. 5, pl. 3). A small excavation of five barrels showed that they contained variously: congealed blubbery oil, dismembered penguin pieces in solidified oil and whole giant petrels (which may have fallen in while trying to eat the oil). The casks appeared to be stacked ready for taking off. They are probably best interpreted as the last cache of the first sealing period, abandoned for some reason presumably by the last sealers to work that end of the island.

Red Island had a small cache of six barrels sitting end up. The date of this site is unclear.

A number of barrels and barrel pieces have been found at Atlas Cove. Some of these bear the stencilled marks of the 20th-century Kerguelen Whaling and Sealing Company.

\section{Hut ruins}

Stone hut ruins have been found on virtually all the sealing beaches. There is a variety of hut styles and evidence of the use of a variety of materials.

The hut at Long Beach has already been mentioned as it was the only one to be built on a platform (fig. 6, pl. 4). The hut was rectangular and smaller than the mound. Stone footings survived to a height of $0.75 \mathrm{~m}$, together with four upright wooden posts and the remains of six orhers. There was also evidence for the use of turves in the construction. The hut was probably roofed with a sail or with seal skins as the two largest upright posts were peppered with a variety of copper and iron nails which may have held the roofing material in place. The quantity and variety of nails may be the result of re-covering the roof, perhaps many times, with new material as the old one wore out. The probable appearance of this hut has been reconstructed 


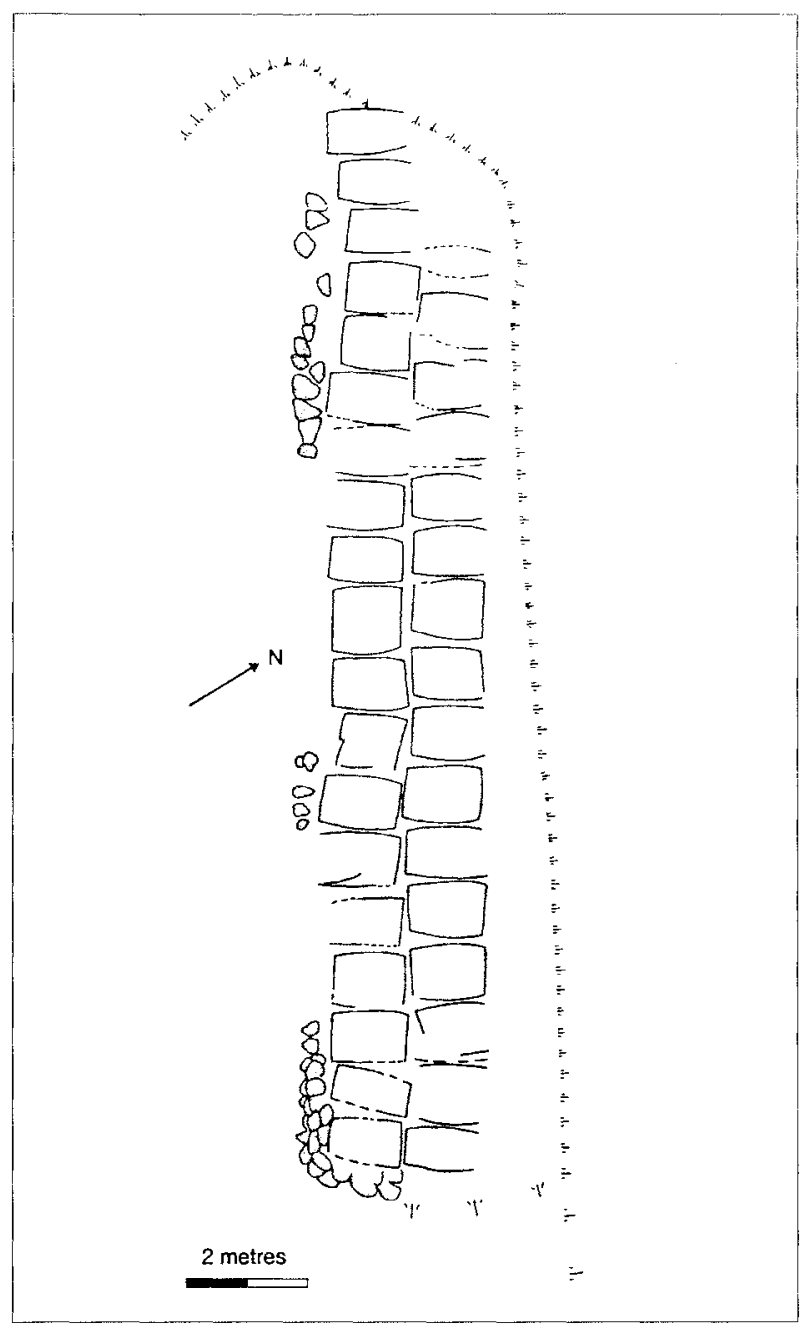

FIG. 5-Detailed plan of barrels at Oil Barrel Point, Heard Island 1986-87.

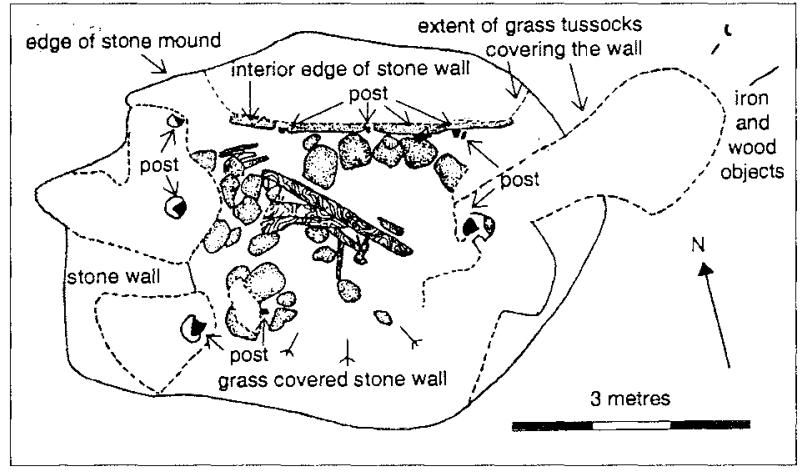

FIG. 6 - Plan of hut site at Long Beach, Heard Island $1986-87$.

from our field notes by Simon Hayman of the Department of Architectural Science at the University of Sydney and is shown in figure 7.

There is documentary evidence for the use of sail and skin roofs by 19 th-century sealers elsewhere on Heard Island (Crowther 1943: 553). The erection by sealers of turf-walled huts roofed with sails and skins or grass thatch on wooden or whale bone rafters is well documented on the Kerguelen Islands and on Heard Island (Clark 1887: 436, Nunn 1850: 87, 97, 121, 162).

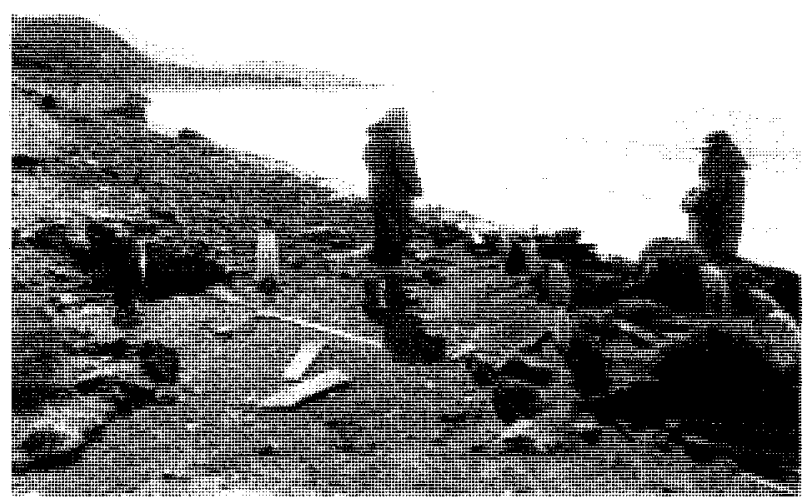

PLATE 3

Recording the barrel cache at Oil Barrel Point (see also fig. 5).

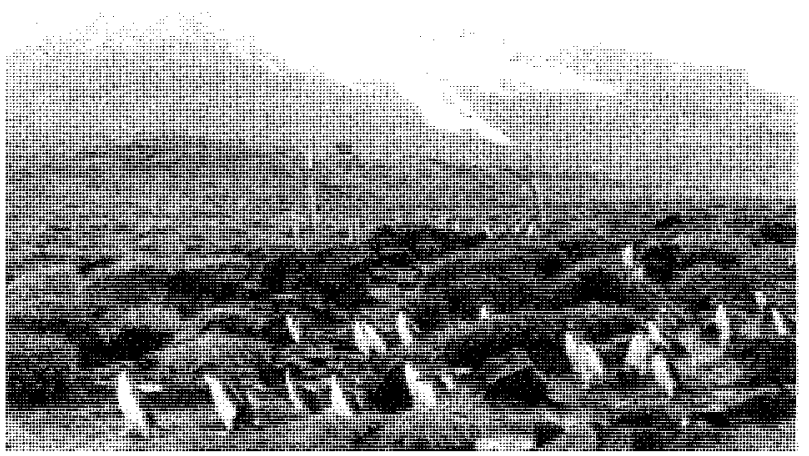

PLATE 4

Hut remains at Long Beach.

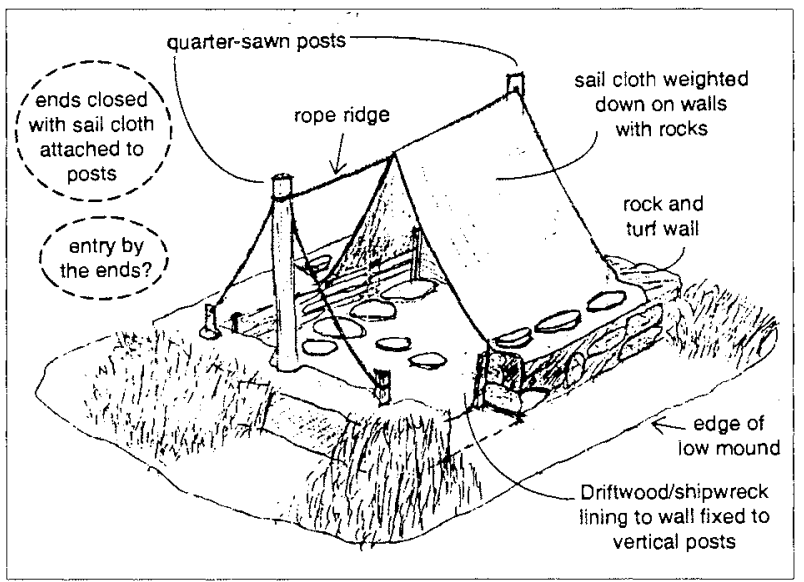

FIG. 7-Architect's reconstruction of the sealers' hut at Long Beach, cut away to show the construction and interior.

There is some contradiction in the documentary sources as to whether or not seals were actually slain and processed at Long Beach. Moseley (1879: 227), the naturalist with the 1874 Challenger expedition, reported that he was told by sealers at Corinthian Bay that seal killing and processing did not take place on Long Beach, but that men lived there in order to drive seals back into the water so they would 
haul up in a more convenient place. Clark (1887: 421) also stated that men were sent over from the other side of the island to live here in order to drive off the seals. Thomson \& Murray (1885: 377) in the official narrative of the Challenger expedition confirmed that this activity took place but stated also that blubber was collected at Long Beach and transported over the glaciers to Spit Bay. The location of the site amongst the wallows, together with the fact that some effort has gone into building a platform here despite the well-known existence of a small but habitable cave nearby on the moraine, suggests that the function of the mound, initially at any rate, may have been industrial. The reconstructed archaeological evidence suggests that the last structure on the mound was a stone-based tent/hut more suited to interpretation as a domestic site than a tryworks. By the 1870 s and 1880 s the mound provided a convenient structure for siting a living hut, and it is the remains of this perhaps secondary structure that have survived.

At Spit End, the living huts were located up on the moraines, often in the lee of large boulders. All the huts recorded in 1986-87 by McGowan and Lazer had a rectangular floor plan, with the exception of one of the Sealers Beach huts which may have been L-shaped. Burton \& Williams (1985) reported one round and two elliptical structures at South West Bay Beach. This type of hut has not been found elsewhere at Heard Island and the date of this site is uncertain. Small, low, circular stone structures have been reported from Prince Edward Island, where they have been interpreted as Macaroni penguin holding bays (Cooper \& Avery 1986: 22 and fig. 10). Only one of the huts examined, the L-shaped hut at Sealers Beach, seemed to be internally divided into rooms. Sizes range from $15.5 \mathrm{~m}$ x $10 \mathrm{~m}$ at Sealers Beach to $4 \mathrm{~m} \times 3.25 \mathrm{~m}$ at Saddle Point.

At Sealers Beach we recorded the remains of three large huts close to each other. These huts consisted of stone footings with wooden upright posts (figs 8,9 , pl. 5). The large quantity of fallen wooden boards inside these huts indicated that the walls were made of boards fixed to the wooden uprights. Possibly the roofs were made of wood also, or they may have been thatched or covered with sailcloth or skins, which probably would have left little archaeological evidence. The eastern hut may have been partly floored with cobbling. The central hut had two porched entrances, half-way along the west wall and on the south side. Both entrances had external stone porches, which were built as a protection from the weather. A similar porch constructed of turves was described for a hut built from an upturned boat on Kerguelen Island (Nunn 1850: 217):

We were anxious to build out the walls, one on each side of the doorway, as we found these effectual in defending us from the storms of hail and snow to which we were always subject in this ungenial clime.

The huts on the northwestern beaches of Heard Island were generally smaller and were typically stone-wall huts lined with wooden boards or planks. This construction was seen most clearly at Corinthian Bay. The hut was built in the second half of the 19th century but was also used during the second sealing period in the 1920s. It was probably renovated at this time, as the first ANARE expeditioners remarked on its good state of preservation (Scholes 1949: 95-96). The stone walls were between
1 and $2 \mathrm{~m}$ thick enclosing a rectangular wooden hut $3.5 \mathrm{~m}$ x $4.5 \mathrm{~m}$ with a single pitch wooden roof. Scholes also mentioned the use of corrugated iron. A photograph taken in 1902 by E. Vanhoeffen and published by Drygalski (1912) showed the stone walls rose to two-thirds the height of the hut. A gap in one wall formed a small internal porch allowing access to the hut door. This hut did not have a chimney, although in 1948 a stove was reported inside. The huts at Red Island and Saddle Point also seemed to follow this design, with some evidence of stone footings with an internal wood lining, although in 1986-87 there were no surviving standing walls.

Other domestic sites, at Try Pot Beach and Spit Bay North, were indicated by scatters of domestic artefacts, although any obvious structural evidence had disappeared. Both sites must have had huts but have been so disturbed that any evidence of their form is gone, although dressed and moulded timber was found at both sites in 1986-87.

The archaeological evidence indicates that sealers' huts were more substantial than might be thought likely from contemporary descriptions of the living conditions. The crew of Captain Robinson's Tasmanian ship Offley arrived at Heard Island in 1858 expecting to live in tents. Unfortunately the supply tender carrying their tents and tools was lost, so the crew was forced to build shelters with whatever came to hand.

Spare oars were used as roof beams, seal skins were used as roofs and tents made from sails and tarpaulins.

In a perhaps exaggerated account which was written by several of the crew for use in a lawsuit against the ship's owners, the building of their "miserable abode" was described thus (Crowther 1943: 553):

We were ordered on shore upon an island covered with ice and snow and with snow falling. At length we succeeded in finding some old portions of a wreck and managed to erect a place large enough for us to crawl into. We were fully two days in erecting these few poles and a sail over them where we had to exist for upwards of six months, huddled together far worse than sheep, our fireplace tussocks of grass and our fuel Elephant's blubber and penguin skins.

Of the living conditions at Spit Bay, Captain Robinson said (Crowther 1970: 307):

... the men's huts were very dirty and smoky; penguin blubber, or any kind of blubber, is the only fuel used, no chimneys to the huts that I can remember.

None of the huts recorded in 1986-87 appeared to have a chimney, except perhaps one of the Sealers Beach huts, which has an iron "Pacific" stove set into a bay in one corner.

All the stone-based hut sites are thought to date from the second half of the 19th century. Many of the sites have artefact or documentary evidence of construction or use at that time. Some huts, such as the Corinthian Bay hut, were re-used in the 1920s. The only hut known to have been built in the 1920s is Admiralty Hut built by sealers for the British Admiralty at Atlas Cove (Keage 1981:14). It is a small six-sided hut, built entirely of wood and is very different from the much larger and earlier stone-based huts (pl. 6). It had a stove and a stove-pipe chimney, which operated so inefficiently that when it was lit the door had to be left open for ventilation (Fletcher 1984: 95). 


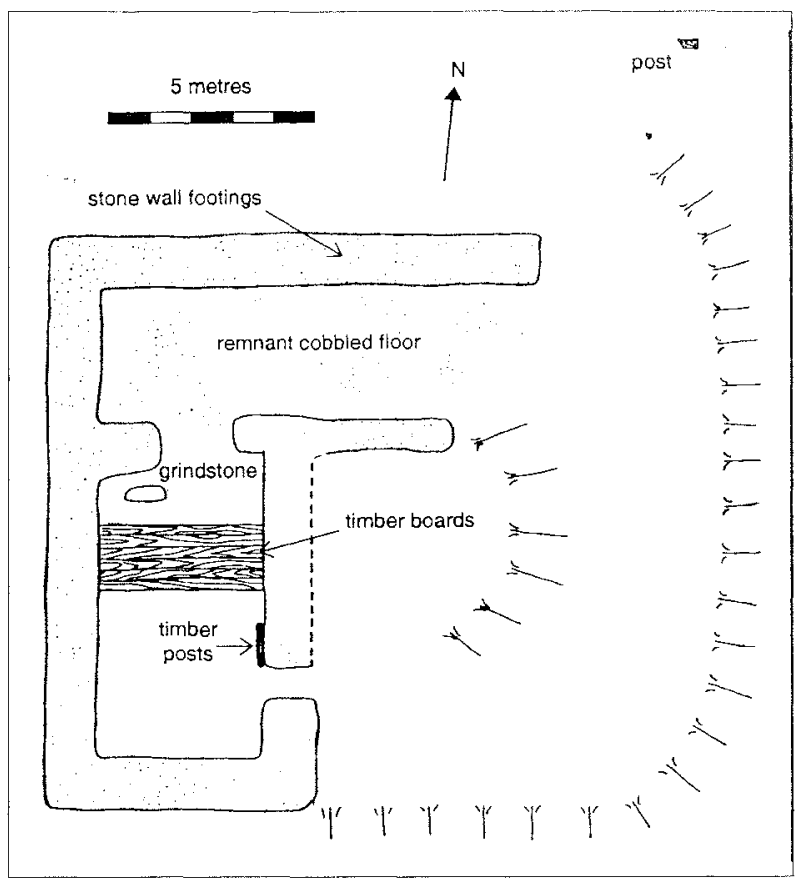

FIG. 8-Plan of eastern hut at Sealers Beach, Heard Island $1986-87$.

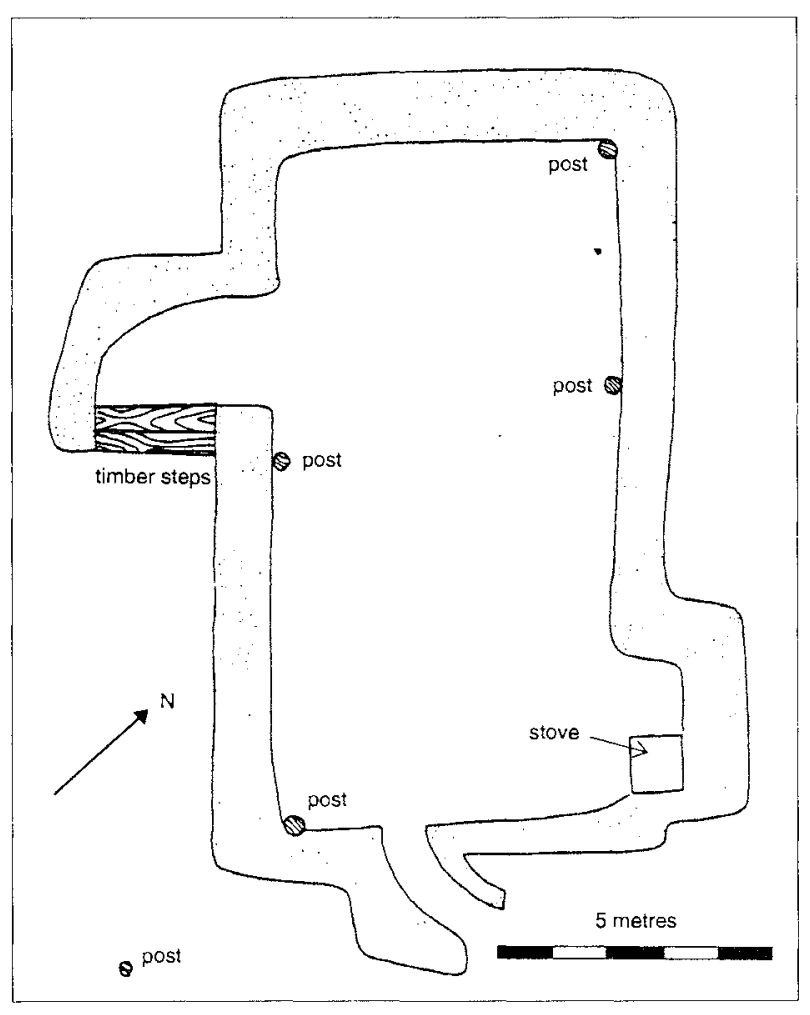

FIG. 9- Plan of central hut at Sealers Beach, Heard Ysland 1986-87.

The first recorded group of sealers to winter at Heard Island, in 1856, are said to have lived in square holes dug in the ground and covered with wooden boards, moss and snow (Lanman, quoted in Law \& Burstall 1953: 2). Moseley, from the 1874 Challenger expedition, also found sealers living in holes under wooden roofs (Moseley 1879:

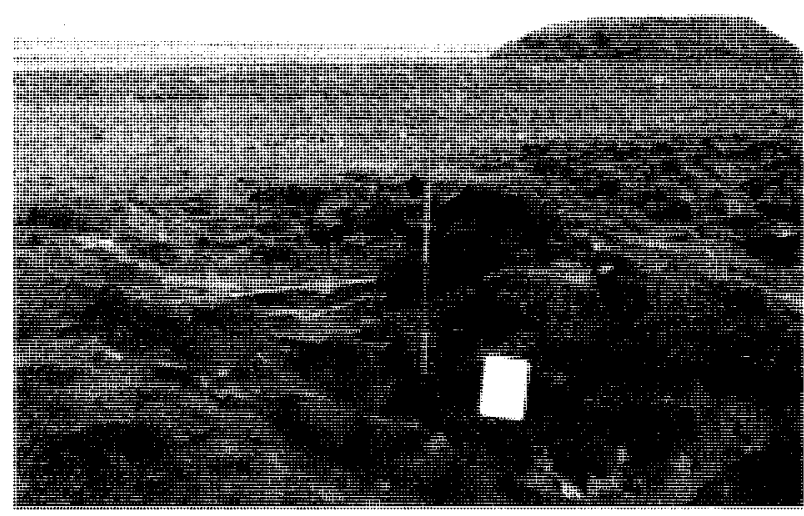

PLATE 5

Remains of eastern sealers' hut at Sealers Beach.

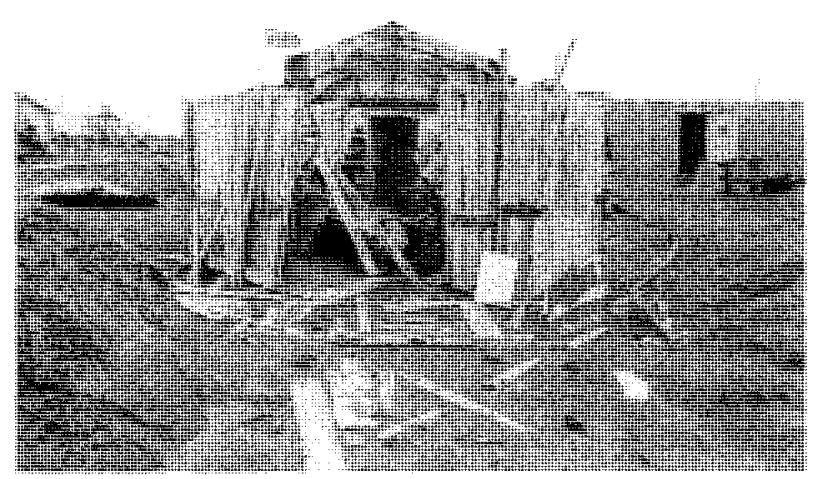

PLATE 6

Remains of Admiralty Hut, Atlas Cove.

229). Anne Robb found a pit hut adjacent to the standing Corinthian Bay hut ruins in 1987-88 (Robb 1988: 155).

\section{Occupied Caves}

Many lava caves occur around Heard Island. One at Red Island and a cave in a moraine at Long Beach had evidence of occupation. Another hut site at Red Island was located in the shelter of a lava overhang.

Both the occupied caves are small, $4 \mathrm{~m}$ deep at the most, and both contained items of structural timber, showing that their sheltering properties had been improved upon. The date of the Red Island cave occupation is unclear but it may have been used during both sealing periods. The Long Beach Cavern was a landmark that was well-known to the sealers in the late 19 th century, being marked on an American sealers' map of "Hurd's Island" (sic) (Bertrand 1971: 234). It is big enough to protect about three people from the worst of weather.

Not surprisingly, sealers have always been ready to take advantage of the natural shelter offered by caves, and this type of occupation is also found on other Subantarctic sealing islands. Sealers occupied two caves on Marion Island, both of which had substantial stone walls at their entrances Two rock overhangs also provided shelter and contain equipment and camp refuse (Cooper \& Avery 1986: 17, 19). Three occupied caves with stone or earth walls and two overhangs with timber, equipment and tent debris were reported from Prince Edward Island (Cooper \& Avery 
1986: 19, 23). Caves were used by shipwrecked sealers and later expeditions on Macquarie Island (Davies 1982, Townrow 1989: 124-125).

\section{LIVING AND WORKING ON HEARD ISLAND}

To a certain extent it is possible to argue which sites on Heard Island were used primarily for domestic and which for industrial purposes. These functions have been identified primarily on the basis of the structures of the sites themselves and the diagnostic artefacts found associated with them. Descriptions and identifications of the artefacts recorded at the sites together with a preliminary analysis of these material culture remains, was undertaken by Estelle Lazer and was reported in detail in Lazer \& McGowan (1989:39-59). The following types of artefacts have contributed to identifying the function(s) and date of use of the sites: trypot, ammunition, scrap blubber press, butchered seal bone, copper oil cooling tank, blubber skimmer, blubber fork, lance, hook, iron bar, barrel, axle, tryworks hearth, grindstone, cast iron stove, clay smoking pipe, domestic ceramics (plates, bowls, jugs), bottle glass, knife, clothing (boot, shirt, buttons), copper and iron nails, wooden floors and posts.

On the northwestern side of the island, the functional differences of the sites appear less clear cut. Where site functions can be distinguished, it appears that the working areas were very close, if not adjacent, to the living huts. For example at Corinthian Bay trypots and an extensive scatter of artefacts including sealing equipment and domestic pottery were found within $20 \mathrm{~m}$ of the hut.

At the Spit end of the island, there seems to have been a clearer separation between living and work areas. In general, the work platforms are down near the beach and constructed so as to overcome the environmental disadvantages of that location. The living huts are up on the moraines, often in the lee of large boulders and above the worst of the seal wallows. However, some industrial activities seem to have been undertaken on the moraine at Sealers Beach, as evidenced by the presence of a number of sealing artefacts including pieces of trypot up there. At Long Beach, a stone work platform may have been re-used by the last sealing party to stay there as a domestic hut, although the evidence for function here is inconclusive.

At the southeastern end of Heard Island, we found a series of working platforms on the beaches and a number of domestic sites on the moraines. In most cases I would not like to link particular working platforms with particular living huts. However, at Sealers Beach, it seems that the group of three huts on the moraine must be associated with the tryworks below. Although badly damaged by seals, there was enough left of the layout of the site for a thorough survey of artefacts, from which it would probably be possible to determine activity areas on the moraine. Does the arrangement of the three huts represent a chronological progression, contemporary functional differences or contemporary social differences?

I would argue that the two sets of sites, at the northwestern and eastern (Spit) ends of the island, are sufficiently dissimilar in character to suggest differences in the way the industry was operating. On the northwestern beaches, there appears to have been a wide variety of domestic architectural forms, including rectangular wood-lined stone huts at Corinthian Bay, Red Island and Saddle Point, pit dwellings at Corinthian Bay, elliptical stone-based huts at South West Bay and modified caves at Red Island, as well as the six-sided wooden Admiralty Hut at Atlas Cove. At all locations where there are diagnostic artefacts and structures, domestic and industrial functions were either located very close to each other, or there does not appear to be a specific separate industrial area. "This suggests to me a pattern arising from a number of individual operations, which did not have much contact with each other or at least not enough contact to share a common vision of the way things should be done. These different styles of sites may have been built and used by sealing gangs that were from different ships, most likely in different years, and possibly in competition with each other. These camps were probably used and re-used over longer periods of time. The last sealers to work on Heard Island, the Kerguelen Sealing and Whaling Co., were based at Atlas Cove in the 1920s, where they left various items of equipment branded with their name, used the Corinthian Bay hut and were engaged to construct the small wooden Admiralty Hut.

On the eastern, Spit End, beaches, the sites show such strong formal similarities (especially in comparison to the stylistic anarchy of the northwestern beaches) that I would argue that they almost certainly resulted from the same (or at least related) operations. Firstly, the distribution of the sites appears to demonstrate a clear and consistent separation between the industrial and domestic areas, with the tryworks located down on the beaches and the huts located up on the moraines. The tryworks themselves also show a strongly shared formal style. All were constructed on stone platforms, an architectural style which appears uniquely characteristic of this suite of sites. The high level of similarity between the sites at Spit End suggests that these sites were not only built (or more likely rebuilt from earlier structures) and operated by the same (or closely related) groups of sealers, but they were not reoccupied and altered subsequently. That is, the last sealing expedition to operate in this part of the island operated in a co-ordinated manner on a large scale across the whole of this end of the island, rather than comprising a number of smaller unrelated or rival operations. There is no archaeological evidence that this part of the island was reworked by sealers in the 1920 s.

This suggestion makes this suite of sites at Spit End particularly valuable, firstly for their ability to provide rich material for a study of contemporary intersite variability, and secondly because this enables the sites, their technology and the period of use of their material culture to be reasonably accurately dated. The last documented sealing expedition at this end of the island took place in the $1880 \mathrm{~s}$ when the Trinity was wrecked. The shipwrecked crew were marooned for 15 months from October 1880 to January 1882 (Bertrand 1971: 251-252, Busch 1980: 121). The archaeological evidence is that, during this time, they constructed a substantial camp on the moraine above Sealers Beach and continued to work the Spit End beaches systematically, right up to the moment of rescue. The large cache of full barrels abandoned at Oil Barrel Point suggests that, when rescue came, the sealers were not really prepared. It is unlikely that they would have abandoned this valuable cargo unless conditions were exceptionally bad. Perhaps the captain intended to return later to pick them up, but no-one ever did. 


\section{FUTURE RESEARCH POSSIBILITIES}

In concl usion I would like to suggest a number of specific interprecation frameworks for archaeological research at Heard Island, all of which are fundamentally related to the theme of isolation.

\section{Changes in technology and industrial processes}

A range of movable artefacts and structures have been recorded associated with sealers' sites on Heard Island. Relating these to the two documented periods of sealing activity, may provide the opportunity to trace technological progress in the sealing industry over some 80 or more years. The unique stone working platforms are items of particular interest.

\section{Social separation and isolation}

How did the sealers' society function on the island in the light of these and other social issues?

For example, we know from documentary sources that the sealing gangs on Heard Island contained some discrete ethnic groups who were said to be living separately. These groups included Americans and Africans, who were known generically as Cape Verde Islanders (because this was where they joined ships' crews as a means of gaining passage to America). Race was fundamental to their social relations, and different ethnic groups occupied separate quarters, at times racial tensions flaring (Busch 1985: 175-179). The intra- and intersite distribution of specifically American or African/Cape Verde/Portuguese artefacts may provide information about the relationships between different ethnic groups, enabling the degree of social separation inferred from historic sources to be tested and/or demonstrated. In a more general sense, such an approach could examine the potential of the archaeological record to determine social arrangements and status within a community. Taking this idea further, the archaeological expression of ethnicity on Heard Island could then be compared to other sealing communities with distinctive ethnic groups, such as the Bass Strait Islands, which comprised American and British men and Tasmanian Aboriginal women.

Another example: Subantarctic sealing communities were very male societies. Only one woman, a captain's wife, is recorded as having made a very brief visit to Heard Island. Comparison of the archaeological remains of these exclusively men's camps with mixed sealing communities such as those on the Bass Strait islands may provide the opportunity to contribute to gender studies based on the historical archaeological record.

\section{Economic history}

The 19th-century sealing industry was a global enterprise, based initially in Britain and America and later in the colonies, and conducted on the widely dispersed shores around the Southern Ocean. The markets for seal products were in America, Europe and China, and provided those captains who survived the hazards with enormous profits. Archaeological remains on Heard Island and other sealing regions have the potential to contribute to broad questions concerning the organisation of the sealing industry, the technology and the international commercial networks.

\section{Colonisation of the world}

This is one of the great recurring themes in archaeology. The remote sealing settlements, such as those found on
Heard Island, have a great potential to contribute to this discourse. In my opinion we should view these communities as temporary outposts, remote and isolated from their economic and cultural focus, rather than pioneers of colonisation. These Subantarctic sealing communities clearly never intended to establish themselves as colonies. They never (or at least rarely) included women, were always shortlived and concentrated their economic activity on accumulating huge quantities of resources for removal rather than following a long-term subsistence strategy. As such, these settlements provide an archaeological contrast to the remains of both successful and unsuccessful colonisation attempts elsewhere, perhaps enabling the archaeological characteristics of pioneer colonising settlements to be more readily recognised.

\section{CONCLUSION}

If I were asked to sum up the archaeology of Heard Island in one word, I would say it was about "isolation". Heard Island (with perhaps other sealing islands in the Subantarctic region) offers the opportunity to study the archaeology of communities in isolation and this is the fundamental theme underlying its history and archaeology:

- its enormous geographical isolation;

- the consequent isolation of a commercial product from its markets;

- the isolation of remote outposts of society far from home and the source of all supplies;

- the physical separation of the gangs around the island from each other by huge rivers of ice;

- the isolation of men from the society of women;

- the social isolation of different ethnic groups, even in the face of dire circumstances or perhaps because of it, as a way of maintaining a cultural link with the mores of home.

Study of the material cultural remains on Heard Island has the potential to significantly contribute to the development or discussion of all these issues - and doubtless more.

The largest and best sites are fast disappearing along with all their information, their potential for understanding the history of a major 19th-century global industry and their wonderful collection of objects. This is a crisis situation, probably the single most serious issue currently needing to be addressed on Heard Island.

\section{ACKNOWLEDGEMENTS}

I especially want to thank my colleague, Estelle Lazer, who undertook the joint field project with me, and to acknowledge her contribution to our discussions and debates on the interpretation of the field evidence. I must take responsibility for the particular arguments and interpretations presented here, with which Estelle may not necessarily agree.

I also wish to thank the other members of the 1986-87 ANARE to Heard Island. Dana Bergstrom, Roger Guard, Peter Keage, Rod Ledingham, Dave Sheahan, Jack Stephenson and Pip Turner helped us in recording field data. The figures were drafted from our wallow-stained field notes by Ian Skinner, except figure 6 drawn by Estelle Lazer and the figure 7 reconstruction by Simon Hayman. All drawings have been revised and relettered by myself for this publication. 
The fieldwork was funded by an Antarctic Science Advisory Committee grant, with substantial additional contributions from the Australian Heritage Commission and Australian Geographic. Logistical support was provided by the Antarctic Division of the (then) Department of Science, and some vital surveying equipment was loaned by the Tasmanian Museum and Art Gallery.

My thanks also ro my current employers, the (now) Department of Primary Industries, Water and Environment, for supporting my attendance at the July 1998 Heard Island Workshop.

\section{REFERENCES}

ALLISON, I.F. \& KeAGE, P.L., 1986: Recent changes in the glaciers at Heard Island. Polar Rec. 23 (144): 255-271.

BERTRAND, K.J., 1971: AMERICANS IN ANTARCTICA 1775 1948. Am. Geogr. Soc. Spec. Publ. 39. Lane Press.

BuDD, G.M., 1998: Changes in Heard Island glaciers, king penguins and fur seals between 1947 and 1971. In Selkirk, P. (Ed.): HEARD ISLAND WILDERNESS RESERVE: REPORTS ON NATURAL SCIENCE AND CULTURAL HERITAGE RESEARCH. ANARE Res. Notes 101. Australian Antarctic Division.

Burton, H.R. \& Williams, D.L., 1985: Heard Island ANARE 1985 report. Unpubl. rep. Antarct. Div., Dep. Sci.

Busch, B.C., 1980: Elephants and Whales: New London and Desolation, 1840-1900. Amer. Neptune XL(2).

BusCH, B.C., 1985: THE WAR A GAINST THE SEALS. McGillQueens University Press, Kingston, Canada.

Campbell, Lord G., 1876: LOG LETTERS FROM "THE CHALLENGER". Macmillan, London.

Clark, A.H., 1887: The Antarctic fur-seal industry. In Goode, G.B. (Ed.): The fisheries and fishery industries of the United States, Section 5. Hist. Methods 2(18): 400-467. Government Printing Office, Washington.

COOPER, J. \& AVERY, G. (EDS), 1986: HISTORICAL SITES AT THE PRINCE EDWARD ISLANDS. S. Afr. Natl Sci. Prog. Rep. 128. Council for Scientific and Industrial Research, Pretoria, South Africa.

Crowther, W.E.L.H., 1940: A whaling voyage to the south in the fifties. Script of a broadcast 5 October 1940. Unpubl. MS in W.L. Crowther Library, State Library of Tasmania.

Crowther, W.E.L.H., 1943: A surgeon as whaleship owner. Med. J. Aust. 1(25): 549-554.

CROWTHER, W.E.L.H., 1970: Captain J.W. Robinson's narrative of a sealing voyage to Heard Island, 1858-60. Polar Rec. 15(96): 301-316.

Davies, M., 1982: Macquarie Island: Archaeological report. Unpubi. rep. Tasm. Natl Parks Wildl. Serv.

DOWNES, M., 1996: Indexing sealers' logbooks from Heard Island. ANARE Res. Notes 97.

DRYGAISKI, E. vON, 1912: Geographie von Heard Insel. In Drygalski, E. von (Ed.): DEUTSCHE SUDPOLAREXPEDITION 1901-1903. II Band. Geographie und Geologie. George Reimer, Berlin: 223-239.

FLETCHER, H., 1984: ANTARCTIC DAYS WITH MAWSON: A PERSONAL ACCOUNT OF THE BRITISH AUSTRALIAN AND NEW ZEALAND ANTARCTIC EXPEDITION OF 1929-31. Angus and Robertson, Sydney.

Green, K., 1998: In Selkirk, P. (Ed.): HEARD ISLAND WILDERNESS RESERVE: REPORTS ON NATURAL SCIENCE AND CULTURAL HERITAGE RESEARCH. ANARE Res. Notes 101. Australian Antarctic Division.
HARRIS, S., 1988: A catalogue of some cultural relics in the Outer Furneaux Islands. Unpubl. rep. Aust. Natl Parks Wildl. Serv.

KFage, P.L., 1981: The conservation status of Heard Island and the McDonald Islands. Environ. Stud. Occ. Pap. 13. University of Tasmania, Hobart.

LAW, P.G. \& BURSTALL, T., 1953: Heard Island. ANARE Interim Rep. 7. Antarctic Division.

Lazer, E. \& MCGOWan, A., 1987: Archaeological survey of sealing sites at Heard Island, 1986-87. In Antarctic Division, Planning and Co-ordination Section (Eds): 1986-87 Australian Antarctic Research Program: initial field reports. Antarctic Division, Department of Science: 205-212.

LAZER, E. \& MCGowan, A., 1989: Heard Island Archaeological Survey 1986-1987. Unpubl. rep. Aust. Heritage Commn.

LEDINGHAM, R., 1987: Heard Island Expedition ANARE. 1986 87. Rep. to Aust. Antarct. Div.

MCGowan, A., 1988: Heard Island. Aust. Geogr, 9: 58-79.

MCGOWAN, A., 1998: In Selkirk, P. (Ed.): HEARD ISLAND WILDERNESS RESERVE: REPORTS ON NATURAL SCIENCE AND CULTURAL HERITAGE RESEARCH. ANARE Res. Notes 101. Australian Antarctic Division.

MCGOWAN, A. \& LAZER, E., 1988: A survey of sealing sites on Heard Island. Parts $1 \& 2$ ( 2 vols), Unpubl. rep. Aust. Heritage Commn.

Moseley, H.N., 1879: NOTES BY A NATURALIST ON HMS "CHALLENGER". John Murray Press, London.

NunN, J. (ed. Clarke, J.), 1850: NARRATTVE OF THE WRECK OF THE "FAVOURITE" ON THE ISLAND OF DESOLATION DETAILING THE ADVENTURES, SUFFERINGS AND PRIVATIONS OF JOHN NUNN. Painter, London.

RICHARDS, R., 1981: The journal of Erasmus Darwin Rogers, the first man on Heard Island. Am. Neptune October 1981: 280-305.

Roвв, A., 1988: Archaeological site survey on Heard Island: North West Coast. In Antarctic Division, Planning and Co-ordination Section (Eds): 1987-88 Australian Antarctic Research Program: initial summary of research activity. Antarctic Division, Department of Science: $155-$ 156.

RoberTs, B., 1950: Historical notes on Heard and McDonald Islands. Polar Rec. 5(40): 580-584.

Robinson, J., n.d.: Reminiscences. Unpubl. MS in the W.L. Crowther Library, State Library of Tasmania.

SCHOLES, A., 1949: FOURTEEN MEN: THE STORY OF THE AUSTRALIAN ANTARCTIC EXPEDITION TO HEARD ISLAND. Cheshire, Melbourne.

SELKIRK, P. (ED.), 1998: HEARD ISLAND WILDERNESS RESERVE: REPORTS ON NATURAL SCIENCE AND CULTURAL HERITAGE RESEARCH. ANARE Res. Notes 101. Australian Antarctic Division.

Shaughnessy, P.D., Shaughnessy, G.L. \& Keage, P.L., 1988: Fur seals at Heard Island: recovery from past exploitation? In Augee, M.L. (Ed.): MARINE MAMMALS OF AUSTRALASIA — FIELD BIOLOGY AND CAPTIVE MANAGEMENT. Royal Zoological Society of New South Wales, Sydney: 72-77.

Thomson, C.W. \& Murray, J., 1885: REPORT ON THE SCIENTIFIC RESULTS OF THE VOYAGE OF HMS "CHALLENGER" DURING THE YEARS 1873-76. NARRATIVE VOL 1. FIRST PART. HMSO, London.

TOWNROW, K., 1989: SURVEY AND EXCAVATION OF HISTORIC SITES ON MACQUARIE ISLAND. Occ. Pap. 20. Department of Lands, Parks and Wildlife. Tasmania. 